\title{
Developing Strategies for Increasing Market Share of Turkey on Health Tourism by Using Fuzzy AHP Method
}

\author{
Türkiye'nin Sağlık Turizmi Pazar Payını Arttırıcı Stratejilerin Bulanık AHP Yöntemi Kullanılarak Geliştirilmes \\ Yeter DEMIR USLU ${ }^{1}$, Erman GEDİKLİ ${ }^{2}$ Emre YILMAZ ${ }^{3}$, Ayşegül ÇIÇEK ${ }^{4}$, Mervenur KARATAŞ$^{5}$, \\ Seda AYDIN ${ }^{6}$
}

\begin{abstract}
ABSTARCT
The purpose of this study is to develop health tourism strategies in order to get more share of the international market. In this scope, firstly the negatives for health tourism of Turkey are examined by researching literature. Then a fuzzy AHP (Analytic Hierarchy Process) method was employed in the study. The decision-making group consists of the health tourism and management and strategy experts of hospital and university who have at least twelve years of experience. According to analysis findings, decision makers primarily chose the subjects of Insufficient legal sanctions for faulty applications, lack of coordination with agencies and insurance companies abroad and insufficient number of physicians and health personnel who can speak a foreign language and qualified. For increasing market share of Turkey on health tourism priority strategies can be as follows; legal regulations should be made that are comprehensive, future-oriented and protect all stakeholders, including important organs of the public and private sector and complication insurance may be required, in order to ensure the coordination of national and international stakeholders, the conference, fairs and events should be increased and each stakeholder should be taken into account, and finally in order to increase the foreign language skills of physicians and healthcare personnel, it is necessary to cooperate with Ministry of Health, Ministry of National Education and Universities.
\end{abstract}

Keywords: Health Tourism, Developing Strategies, Multi-Criteria Decision-Making Methods, Analytic Hierarchy Process

\section{ÖZ}

$\mathrm{Bu}$ çalışmanın amacı, Türkiye'nin uluslararası sağlık turizmi pazarından daha fazla pay alabilmesi için strateji önerilerinde bulunmaktır. Bu kapsamda öncelikle Türkiye'nin sağlık turizmine yönelik zayıf yönleri literatür taraması yapılarak incelenmiştir. Akabinde çalışmada öncelikli alanların belirlenebilmesi amacıyla Bulanık AHS (Analitik Hiyerarşi Süreci) yöntemi kullanılmıştır. Yöntemde, en az on iki y1llık deneyime sahip, sağlık turizmi ve yönetim strateji alanındaki üç farklı uzmanın görüşleri alınmıştır. Analiz bulgularına göre uzmanlar, hatalı uygulamalar sonucunda yeterli yasal yaptırımların olmamasını, yurt dışındaki acente ve sigorta şirketleri ile yaşanan koordinasyon eksikliğini ve yetersiz sayıdaki yabancı dil bilen, kalifiye hekim ve sağlık personelini öncelikli alanlar olarak seçmiştir. Türkiye'nin sağlık turizminde pazar payını artırmak için öncelikli stratejiler şu şekilde olabilir; geleceğe yönelik, kamu ve özel sektörün önemli organları dahil tüm paydaşları güvence altına alan yasal düzenlemeler yapılmalıdır. Buna ek olarak, Ulusal ve uluslararası paydaşlar arasındaki koordinasyon ve bilgi paylaşımını artırmak amacıyla konferans, fuar vb. etkinlikler artırılmalıdır. Son olarak hekim ve sağlık personelinin mesleki yetkinlerinin ve yabancı dil becerilerinin artırılması için Sağlık Bakanlığı, Milli Eğitim Bakanlığı ve Üniversiteler ile iş birliği yapılması gerekmektedir.

Anahtar Kelimeler: Sağlı Turizmi, Strateji Geliştirme, Çok Kriterli Karar Verme Yöntemleri, Analitik Hiyerarşi Süreci.

${ }^{1}$ Prof. Dr., Management and Strategy, Istanbul Medipol University, yuslu@ medipol.edu.tr, ORCID: 0000-0002-8529-6466

${ }^{2}$ Lec., Health Management, Istanbul Medipol University, egedikli@ medipol.edu.tr, ORCID: 0000-0002-5508-194X

${ }^{3}$ Res. Asst., Health Management, Istanbul Medipol University, emreyilmaz@ medipol.edu.tr, ORCID: 0000-0003-4502-9846

${ }^{4}$ Student, Health Management, Istanbul Medipol University, aysegul.cicek@ std.medipol.edu.tr, ORCID: 0000-0001-7068-9171

${ }^{5}$ Student, Health Management, Istanbul Medipol University, mervenur.karatas@ std.medipol.edu.tr, ORCID: 0000-0003-3257-4650

${ }^{6}$ Student, Health Management, Istanbul Medipol University, seda.aydin@ std.medipol.edu.tr, ORCID: 0000-0003-4272-6574 


\section{INTRODUCTION}

Traveling to places other than where they normally reside, especially to places with thermal and mineral springs and warm climates, in order to get health care is a phenomenon that happened in various geographies in ancient times. The novelty of today's mobility is the radical change in direction and scope. While patients from previously developing countries have turned to Western countries with developed health systems, especially in the last 10 years, the direction of this mobility has generally been turned to developing countries. In addition, the scope of cross-border mobility of patients has expanded. In this context, thanks to the developments in information and communication technologies, it is effective for patients to have information about health services, accommodation and travel services all over the world and to travel to more distant places in a cheap and short time. ${ }^{1}$ In addition to these, price differences between countries, exchange rate differences, exclusion of cosmetics or dental operations from insurance coverage in some countries, increasing medical service marketing, increasing health expenditures day by day with the increase of the elderly population, showing more interest in people's bodies and health, long waiting times, inability to provide gender and abortion opportunities in every country and the active work of travel companies are factors that improve health tourism. $^{2}$

Considering all these, the competitive war between countries in health tourism reveals itself more and more every day and countries are creating a medical tourism plan by considering their rivals. Therefore, the health and tourism sectors in Turkey, thanks to advances that come from the past to today, have begun to enter into competition with countries (India, Thailand, Malaysia, Hungary, Singapore, etc.) with strong medical tourism industries. ${ }^{3}$ In addition, revenue from health tourism, public health care infrastructure, medical knowledge and skills, to improve their technological capacity and health standards can provide financial support for investment. ${ }^{1}$

In terms of health tourism, Turkey is separated from its competitors according to some features. However, this potential is not used enough in Turkey. The geographical location of Turkey, it possesses the technological infrastructure and qualified health personnel by providing health services in the standards of developed countries, besides being also the price advantage, the average waiting times in health care organizations being shorter compared to other countries, it is ranking second in the world after the USA in terms of the number of health institutions accredited by JCI, the existence of a young workforce, the availability of high quality different tourism opportunities that can be integrated with health tourism (belief, culture, etc.) can be classified as our advantages in health tourism. These as well as worldwide resounding success in recent years in organ transplants done and the potential of health tourism in Turkey to reach the point of taking place among the national strategic plans is also the driving force. ${ }^{2,4-9}$ Besides the positive factors transferred here to Turkey for health tourism it is also inadequate and aspects to be developed. In this context, it is aimed to determine the factors that can be considered as negative in terms of health tourism competitiveness and to determine which strategies should be developed primarily with multi-criteria decision-making methods.

\section{Health Tourism}

Health tourism is to cooperate with the tourism industry in order to provide "cost effective" special medical care to patients who require surgical or other medical interventions that require special expertise in general. Health tourism can also be defined as the patients receiving emergency health care or a health service of their choice from different countries. ${ }^{3}$

Health Tourism Coordination Board (SATURK) of the Ministry of Health of the 
Republic of Turkey refers to health tourism "briefly, individuals' visits to a country other than their country of residence in order to receive both preventive, curative, rehabilitative and health-promoting services. Health tourism is a sector that enables the growth of health institutions by using its mobility potential for international health purposes". ${ }^{10}$

The primary health tourism reasons discovered in the 1980s are stated as long waiting times and high treatment costs. There are factors that differ from country to country in the emergence of health tourism. These factors have been synthesized by various studies and gathered in a common denominator. In this direction, factors affecting the choices of health tourists; Political situations of the country, socioeconomic conditions, legislation and other tourism services factors are specified as intermediary institutions. ${ }^{11}$ In addition to all these, it is emphasized that with the development of technology, the emergence of countries that make quality treatments and keep patient safety at the highest level, the decrease in healthcare costs, the development of transportation services, cultural development of individuals and the rise in the desire to visit new places, increase the demand for health tourism. ${ }^{12}$ Conditions that vary according to countries, regions and the characteristics of individuals demanding health services can generally be summarized as follows; ${ }^{13}$

Health systems vary from country to country,

Exchange rate differences,

Differences in economy and income level,

Social, technological, political, cultural, religious differences,

$\checkmark$ Relationships between health care provided and patient satisfaction,

$\checkmark$ Quality of service and cost of service,

Language differences or similarities,

$\checkmark$ Emphasis on patient safety, $\checkmark$ Insufficient laws on malpractice practices,

$\checkmark$ Increases in the number of accredited hospitals.

Changes and developments caused by health tourism throughout the world over time led to the categorization of health tourism in this direction. In this context, health tourism; medical tourism (medical tourism), thermal-spa-wellness tourism, geriatric tourism and disabled tourism is indicated as a type of tourism. ${ }^{14}$

Medical tourism: Travels made from one country to another for treatment purposes are called medical tourism due to reasons such as technological innovations, developing medical and treatment processes, the increase in demand due to the increase of the elderly population and the increase in health expenditures. ${ }^{15}$ According to another definition, medical tourism is defined as carrying out planned country changes in order to increase the welfare level within the scope of mental and physical improvements. ${ }^{16}$ In this context, advanced treatments (cardiovascular surgery, radiotherapy, etc.), transplantation, infertility (IVF applications, etc.), aesthetic surgery, eye, dental and dialysis treatments are specified as medical services. ${ }^{12}$ In addition to these services, the increase in the effectiveness of medical tourism is directly proportional to the coordination of holidayrest and medical needs and the promotional opportunities offered to foreign patients. ${ }^{2}$ In addition, country profile, political environment, qualified personnel, service quality, language similarity, accredited hospitals, hospital hygiene conditions, weather conditions are also among the factors that increase the desire for country change in medical tourism. ${ }^{15}$ In line with all these, hospitals that can only use factors that increase the effectiveness of medical tourism will easily survive in an increasingly competitive environment. Therefore, foresight and preparatory plan 
ning should be made to focus on the obtained reasons.

Thermal Tourism: From past to present, individuals try to find treatment for their illnesses by using thermal water resources in terms of health and the health movements they make towards regions with various thermal water resources for this purpose are called thermal tourism. In this respect, thermal tourism provides a variety of touristic activities for the country that attracts tourists. In addition, it is emphasized as an important type of tourism that we can call the oldest tourism since its history dates to very old times. The striking point of thermal tourism is stated to be the healing effects of chemical-physical components on the body. Based on this information, every country that has a wealth of thermal resources should conduct various studies to benefit from thermal tourism. These studies are emphasized as establishing the facilities based on active earthquake lines, making the established facilities earthquake resistant, facilitating transportation, combining the facilities to be established on the coast with other tourism types or sports branches, and making the promotion supported by various materials. ${ }^{17}$

Spa \& Wellness Tourism: SPA tourism is defined as the treatments made with water, which means "health from water", which have survived from the past to the present. The origin of this word was created by using the initials of the Latin term "Salus Per Aquam". ${ }^{18}$ In other words, it is also known as the practices that make the individual mentally and physically healing or making it healthy, using the healing power of water. Spa-wellness tourism is stated as a type of tourism where medical applications are used as complementary applications, unlike thermal tourism. Wellness is considered as a set of health-enhancing practices that are taught to change habits in an individual's life positively and new vital behaviors. The two names have been combined to make wellness and medical practices more efficient. In this case, this definition, known as "medical wellness", is defined as products and services that take place under the consultancy of doctors and include all kinds of protective applications that provide health and wellbeing. ${ }^{19}$ In line with all these, countries' medical wellness hotels should be established in appropriate locations, products with healthy and rich vitamins should be used, and should be designed to develop wellness tourism based on touristic regions. When compared with Europe only a small fraction of the hot springs in Turkey "spa facilities" are designed according to the standards. For this reason, by designing our spa centers in this area at appropriate standards, we can provide spa tourism to the target audience to a greater extent.

Geriatrics and Disabled Tourism: Geriatrics and disabled tourism are defined as a set of facilities based on a wide audience, which is called "accessible tourism", which enables travel and tourism activities to be delivered to disabled, elderly or people with temporary disabilities. ${ }^{20}$ Elderly tourism, known as "geriatrics" or "third age tourism" in the world, which is effective, life-enhancing and developing, has emerged as a result of the increase in the demand for health with the increasing elderly population. In this context, elderly tourism, which has a great contribution to health tourism, occurred with the direct effect of health expenditures, insufficient capacity and lack of personnel. ${ }^{21}$ On the other hand, it is stated that it creates an important market share in the tourism sector with the perception that disabled people, defined as the most special minority group in the world, cannot travel without their companions. In this direction, disabled tourism started to gain value for every country day by day. In line with all these definitions, in order to ensure geriatric and disabled tourism, efforts should be made to make the legal regulations and implementation conditions of each country suitable for individuals, to organize the necessary activities in tourism companies based on international standards, to minimize costs for future patients, and to provide guide assistance for future patients. 


\section{Health Tourism Perspective of Turkey}

Health tourism, by fostering the tourism sector in the world and Turkey raises and this alternative tourism are gaining importance with each passing day due to the twelvemonth time unlike the seasonal spread of coastal tourism. ${ }^{13}$ Health tourism, with its current structure, has become a sector that enables everyone to access quality health services, increases employment and supports it continuously. The development of health tourism in Turkey offers significant benefits to the country. These benefits contribute to increasingly accelerating information sharing and spreading among countries, expanding expansion of partnership shares, and developing international relations with the global technology and communication network. $^{22}$ People who live in developed countries can access the existing health system in other countries, medical facilities, health services based on quality and economy, through tourism, media, internet and mass media. In this way, the patients who become conscious of are pushing insurance organizations and governments to new searches and structuring in health tourism. As a result, the health tourism market is expanding day by day and attracts the attention of investors. ${ }^{23}$ Considering the success and development in health tourism, India, Thailand, Malaysia, Singapore, Mexico, Germany, South Africa, USA, Brazil and Costa Rica are the leading countries worldwide. ${ }^{24}$

By dint of its geographical location Turkey, Europe is a country that can appeal to a wide audience, covering the Central Asian and Middle Eastern countries. Turkey with appealing to a broad audience and quality health care system has become a prominent medical tourism market. The long coastline, natural beauties, historical sites, archaeological heritage and the gradual development of its physical infrastructure (hotels, transportation vehicles, energy, etc.) provide an important advantage. ${ }^{25}$ The diversity of the different health services offered by low cost are the most important factors feeding the health tourism in Turkey. advancing tourism activities in Turkey is pursuing a parallel course of positive growth in the economy.

In order to increase Turkey's share and competitiveness in the stable growing health and thermal tourism in the world, there have been legislative changes in health tourism in 2011 and The Department of Health Tourism was established under the General Directorate of Health Services. The task of this head of department is to make regulations for the development and improvement of health tourism practices and to publish them, to ensure coordination and competence with the relevant institutions. ${ }^{26}$

The Ministry of Economy, on the other hand, provides financial support to international promotions related to health tourism, and since 2013, a 50\% tax exemption incentive has been received from the revenues from health tourism. ${ }^{23}$

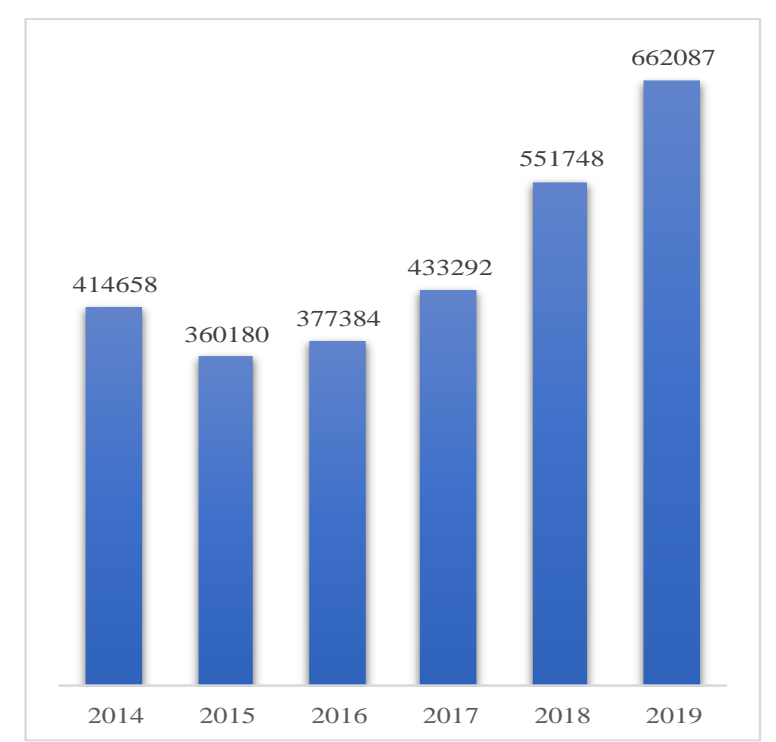

Figure 1. Number of Health Tourists by Years

Turkey has the potential to be the attraction point in the region for health tourism. According to data from the Turkey Statistical Institute (Figure 1) the number of international patients coming to Turkey in recent years has increased regularly. Turkey's health tourism development process was designed especially when the Health Transformation Program was implemented since 2002 with the health services to be more effective in every aspect of the presentation and accessible. Health tourism 
has begun to make its presence felt with the application of modern and high-quality innovation

According to the data authorized by the Ministry of Health and published on the Health Tourism Department website, there are 140 intermediary institutions and 985 health facilities. Intermediary institutions are the first doors to be stolen in health tourism. Patients enter the country through these gates. The first contact between policyholders and foreign insurance companies takes place with intermediary institutions. Intermediary institution; It prepares and maintains special procedures to ensure the provision of special patient needs regarding food, culture, language, religion, legal and ethical issues. ${ }^{27}$ It must be in a mechanism that can respond to all kinds of needs of the patient in the hospital. In summary, the structures authorized to represent the patient to the hospital and the hospital to the patient are intermediary institutions.

According to the data authorized by the Ministry of Health and published on the Health Tourism Department website, there are 985 health facilities. It has a service network operating in 57 provinces, mainly in metropolitan cities. It has been noted that there are 14 facilities in Adana, 105 in Ankara, 90 in Antalya, 25 in Bursa, 382 in Istanbul and 90 in Izmir, the provinces where the density is high. In addition to thermal tourism, in facilities that are distributed in public, foundation and private sectors in medical tourism many fixed services are offered to foreign patients. Such as Plastic and Aesthetic Surgery Orthopedic Surgery
Gamma Knife Pediatric KVC, KVC Neonatal Unit Gastroenterological Oncology Surgery Lung Transplantation, Thoracic Surgery Chest Tumor Surgery Neurosurgery, Perinatology, Epileptic Surgery. ${ }^{9}$ The healthcare facility, which has received at least 85 points from the evaluation of the final health quality standards, is obliged to follow and preserve all the processes of the patient before and after the treatment. By providing all kinds of services, it should store the service it offers in a digital environment. Besides these, Turkey is not determined in any sector of medical tourism with a strategy and criteria. ${ }^{13}$

\section{Literature Review}

The development of health tourism in Turkey offers significant benefits to the country. These benefits contribute to increasingly accelerating information sharing and spreading among countries, expanding partnership shares, and developing international relations with the global technology and communication network. ${ }^{22}$ To increase these positive effects, scientists, ministry of health and industry representatives have conducted various studies.

The data in this study were obtained from studies aimed to boost Turkey's health tourism is collected. Various strategic management tools, such as SWOT analysis, employed in the studies. In this context, Turkey has strengths and weaknesses that the detected vary depending on the year of studies. The negative aspects aimed to develop strategies for this study are summarized in Table 1.

Table 1. Negative Criterions for Health Tourism of Turkey

\begin{tabular}{rr}
\hline References & Negatives for Health Tourism of Turkey \\
Kostak, 2007 & Terrorist incidents in the country (negative image) \\
Advertising and promotional activities are insufficient \\
Insufficient foreign language-speaking physicians and other health personnel \\
Coordination with foreign insurance companies is insufficient \\
Coordination between ministries and sectors is insufficient \\
Inadequate physical and technological infrastructure of public hospitals \\
Cost increases in healthcare \\
The mistakes made in pricing policy \\
The lack of sensitivity at patient rights and in Malpractice applications
\end{tabular}




\section{Table 1. Continuation}

\begin{tabular}{|c|c|}
\hline İçöz, 2009 & $\begin{array}{r}\text { Lack of organization and coordination } \\
\text { Quantitative shortage of qualified staff } \\
\text { Lack of intermediary institutions (providing the coordination of organizations that } \\
\text { will provide travel and health services) } \\
\text { Insufficient promotion of health facilities on web pages } \\
\text { Medical tourism and classical tourism regions cannot be integrated } \\
\text { Insufficient number of experts trained in medical tourism in health institutions yet }\end{array}$ \\
\hline Barca et.al. 2013 & $\begin{array}{r}\text { Lack of integration between sectors (Hotel management, agency, transportation, } \\
\text { insurance, marketing, etc.) } \\
\text { Establishing and developing trust in the sector } \\
\text { Lack of marketing activities } \\
\text { Political instability in neighboring countries } \\
\text { Local health personnel migrating to work abroad, increasing the attractiveness of } \\
\text { working in developed countries } \\
\text { Due to the frequent state interventions in the field of health, sector organizations } \\
\text { (public and private) have to spend time and resources to adapt to the changes } \\
\text { required by these interventions. }\end{array}$ \\
\hline $\begin{array}{r}\text { Omay and Cengiz, } \\
2013\end{array}$ & $\begin{array}{r}\text { Neglecting the importance of marketing } \\
\text { Very few organizations that support health tourism } \\
\text { Poor cooperation between health tourism organizations } \\
\text { The focus is mostly on "tourist health" } \\
\text { Holistic service records and lack of mobility } \\
\text { Brain drains in health } \\
\text { Hack of information systems to share data with the Ministry of Health } \\
\text { High level of bureaucracy } \\
\text { Failure to provide the standard of health services } \\
\text { The negative impact of political instability in Turkey's neighbouring countries, } \\
\text { Lack of domestic accreditation bodies that comply with international standards } \\
\text { Neglecting the importance of marketing }\end{array}$ \\
\hline Kördeve, 2016 & $\begin{array}{r}\text { Diplomatic disputes with neighbouring countries } \\
\text { Increasing costs due to exchange rate } \\
\text { Insufficient promotion (compared to competing countries) } \\
\text { Terrorist incidents in the country } \\
\text { The lack of medical personnel and facilities. } \\
\text { Import of health equipment (external dependency) } \\
\text { Inadequate agreements with international insurance companies and lack of } \\
\text { coordination }\end{array}$ \\
\hline Kılıçarslan, 2019 & $\begin{array}{r}\text { Kidnapped educated young interns (trained) } \\
\text { Foreign language education is weak, and the number of staff who speak the } \\
\text { language less. } \\
\text { The cooperation of the state, NGOs and sector representatives in tourism is not } \\
\text { fully established. (lack of coordination) } \\
\text { Promotion of our health tourism facilities abroad is insufficient } \\
\text { The private health sector may refuse to serve its own people. } \\
\text { Legal sanctions are not effective in malpractices (legal risks) } \\
\text { Competitive pressure from rival countries }\end{array}$ \\
\hline Tontuş, 2019 & $\begin{array}{r}\text { Lack of coordination with related sectors } \\
\text { Insufficient promotional activities } \\
\text { Poor foreign language knowledge of health personnel } \\
\text { the lack of policies at the national level } \\
\text { The mistakes made in pricing policy } \\
\text { Competitiveness of competitors in health tourism }\end{array}$ \\
\hline
\end{tabular}


Table 1. Continuation

Büyüközkan, Mukul and Kongar, 2020
There are complex and uncoordinated legislation in place in practice

Lack of cooperation between ministries

Mobility that allows citizens of European Union countries and the physician does not apply to Turkey.

Healthcare personnel have insufficient knowledge of international health legislation and patient rights

Poor coordination with foreign insurance companies Security concerns

Inadequate medical travel promotion and marketing The additional financial burden of frequent changes in health legislation SATURK, 2020
Relevant legislation is complex and uncoordinated Healthcare personnel not having enough information about international health regulations and patient rights

The scope of application of Turkey on the free movement of health between EU countries

Private and state hospitals have very few health workers who speak foreign languages

In some countries / regions have a negative image about Turkey Inadequate coordination with foreign insurance companies Existence of public hospitals without quality certificates Misapplications in pricing

\section{MATERIAL METHOD}

Firstly, selected criteria based on the literature review will be explained under this section. After that, the significance of these factors will be identified by Fuzzy AHP.

\section{Aspect of Research Ethics}

This study was decided to be ethically and scientifically appropriate by the Istanbul Medipol University Non-Invasive Ethics Committee (Date: 21/01/2020, Decision No: 67, Number: E-10840098-772.02-2599). The study was conducted in accordance with the Helsinki Declaration Principles.

\section{Selected Indicators}

Similar studies in the literature are analyzed to understand the significant criteria for health tourism of Turkey. Consequently, core 8 criterions are determined for the purpose which are representing the negative sides for health tourism of Turkey. These are; insufficient advertising and promotional activities (C1), insufficient number of physicians and health personnel who can speak a foreign language and qualified (C2), lack of coordination between sectors (C3), the mistakes made in pricing policy $(\mathrm{C} 4)$, legislation barriers/inconsistency (C5), insufficient legal sanctions for faulty applications (Malpractice and/or Complication) (C6), diplomatic disputes with neighboring countries (C7), lack of coordination with agencies and insurance companies abroad (C8). After, Fuzzy AHP is used to determine the weights of criteria.

\section{Fuzzy AHP Implantation}

Analytic Hierarchy Process (AHP) is one of the Multiple Criteria Decision-Making (MCDM) techniques firstly established by Saaty. It is a powerful and tool to solve complex decision problems. It solves problems by turning into hierarchical structures through pairwise comparisons Saaty, describes respondents' feelings as exact numbers $(1,3,5,7,9) .{ }^{28}$ Although AHP is an extensive tool, it has some drawbacks. ${ }^{29}$ Ranking of AHP results is imprecise because of its subjective judgment of decisionmakers. Many researchers developed Fuzzy AHP that integrated the fuzzy theory and AHP to overcome this problem. ${ }^{30,31}$

Fuzzy theory is a mathematical theory used to model fuzziness of the human cognitive process, so it is believed to allow researchers more accurate results. ${ }^{29,32}$ In FAHP, the pairwise comparisons are taken from decision-makers on their linguistic 
terms and a scale of 1-9. Then, decisionmakers' pairwise comparisons transformed into triangular fuzzy numbers as it is shown in Table 2.33,34

\section{The Limitations of the Research}

The research has only been searched for the literature. The biggest limitation of the study is that each health tourism stakeholder is not taken into account in detail.

Table 2: Triangular fuzzy numbers used in the research

\begin{tabular}{|r|r|r|r|}
\hline Linguistic Variables & Intensity of importance & \multicolumn{1}{|l|}{$\begin{array}{l}\text { Triangular fuzzy } \\
\text { numbers }\end{array}$} & $\begin{array}{l}\text { Reciprocal triangular } \\
\text { fuzzy numbers }\end{array}$ \\
\hline Equally Strong & 1 & $1,1,1$ & $1,1,1$ \\
\hline Moderately Strong & 3 & $2,3,4$ & $1 / 4,1 / 3,1 / 2$ \\
\hline Strong & 5 & $4,5,6$ & $(1 / 6,1 / 5,1 / 4)$ \\
\hline Very strong & 7 & $6,7,8$ & $(1 / 8,1 / 7,1 / 6)$ \\
\hline Extremely strong & 9 & $9,9,9$ & $1 / 9,1 / 9)$ \\
\hline Intermediate & $2,4,6,8$ & $7,8,9 ; 5,6,7 ; 3,4,5 ; 1$, & $1 / 9,1 / 8,1 / 7 ; 1 / 7,1 / 6,1 / 5 ;$ \\
& & 2,3 & $1 / 5,1 / 4,1 / 3 ; 1 / 3,1 / 2,1$ \\
\hline
\end{tabular}

\section{RESULTS AND DISCUSSIONS}

The criterions were evaluated by 3 experts in the field of health tourism. Table 3 gives the information about the decision makers in detail. The verbal evaluations of decisionmakers are converted to a fuzzy evaluation matrix and the geo- metric mean of them is calculated. After that fuzzy weights are found, relative weights of the criterions are averaged and normalized. Average and normalized weights are given in Table 4.

Table 3. Profiles of decision makers

\begin{tabular}{cccr}
\hline $\begin{array}{l}\text { Decision } \\
\text { Makers } \\
\text { (DM) }\end{array}$ & $\begin{array}{l}\text { Education } \\
\text { Status }\end{array}$ & Experience & $\begin{array}{l}\text { Areas of } \\
\text { Expertise }\end{array}$ \\
\hline DM1 & PhD & 15 years & $\begin{array}{r}\text { Health } \\
\text { Tourism }\end{array}$ \\
DM2 & PhD & 20 years & $\begin{array}{r}\text { Health } \\
\text { Management }\end{array}$ \\
DM3 & MSc & 12 years & $\begin{array}{r}\text { Health } \\
\text { Tourism }\end{array}$ \\
\hline
\end{tabular}

Criterions which decision makers voted; insufficient advertising and promotional activities (C1), insufficient number of physicians and health personnel who can speak a foreign language and qualified (C2), lack of coordination between sectors (C3), the mistakes made in pricing policy (C4), legislation barriers/inconsistency (C5), insufficient legal sanctions for faulty applications (Malpractice and/or Complication) (C6), diplomatic disputes with neighbouring countries (C7), lack of coordination with agencies and insurance companies abroad (C8).

Table 4. F-AHP Average and Normalize Weights

\begin{tabular}{rrrr}
\hline Criteria & \multicolumn{1}{l}{$\begin{array}{l}\text { Average } \\
\text { Weight }\end{array}$} & $\begin{array}{l}\text { Normalize } \\
\text { Weight }\end{array}$ & Rank \\
\hline C1 & 0.112698 & 0.10981129 & 5 \\
C2 & 0.152467 & 0.14856225 & 3 \\
C3 & 0.123715 & 0.12054607 & 4 \\
C4 & 0.070278 & 0.06847770 & 8 \\
C5 & 0.090970 & 0.08863967 & 7 \\
C6 & 0.204929 & 0.19967963 & 1 \\
C7 & 0.092071 & 0.08971246 & 6 \\
C8 & 0.179160 & 0.17457093 & 2 \\
\hline
\end{tabular}

"Insufficient legal sanctions for faulty applications (Malpractice and/or Complication)" are the most important criteria for need improvement to increase health tourism market share with $19.9 \%$ weight.

Afterward, "Lack of coordination with agencies and insurance companies abroad" and "Insufficient number of physicians and health personnel who can speak a foreign language and qualified" criteria are fairly important to $17.4 \%$ and $14.8 \%$. "The mistakes made in pricing policy" is the least important criteria, with $6.8 \%$ weight.

The priority strategy should be the immediate implementation of the regulations that will protect both the patient (health tourist) and the physician and healthcare personnel in responsibilities resulting from malpractice practices or complications. The 
deficiency in this matter has also been noted in previous studies. Such that, Ağaoğlu et al. making the necessary regulations in legislation and laws without losing time, Özkan the current health insurance abroad in this regard Turkey as well be valid, Uyanık Çavuşoğlu informed consent; about the treatment options, the success rates, the responsibilities, the legal aspects and the risk of complications the patient must be informed. ${ }^{36,35,27}$ In cooperation with the healthcare personnel who will treat the patient, the risks and benefits should be finalized, signed and documented completely, Dinçer, et al. stated that institutions should be encouraged to produce certain procedures in possible crisis moments in order to manage the perception of security. ${ }^{37}$

The lack of coordination with agencies and insurance companies abroad has second place in priority health tourism areas. In order to achieve this, it should be supported by conferences, fairs and events to be held to include all stakeholders at national and international level. In addition, the basis for coordination with intermediary institutions should be prepared by ensuring that all health-related outputs such as reports and epicrisis are organized in accordance with international standards. Similarly, Uysal Şahin and Şahin stated that the public should be supported by public policies in order to ensure coordination with insurance companies and agencies abroad. On the other hand, personnel exchanges can also be made to ensure mutual trust in coordination. ${ }^{25}$

Turkey's current health manpower employment point of achieving the objectives of health tourism is inadequate. For this reason, in our study, decision-makers positioned this issue in the third place in terms of priority strategy areas. Cooperation should be made with the Related Ministries and Universities in order to develop this field. Strategic steps should be taken with the consensus reached by all stakeholders. There are also examples of different strategies in studies conducted in this direction. Namely Gülsüm, applied certification programs to employees; Uysal Şahin and Şahin increased education on health tourism; Ağaoğlu et al. determined the training of personnel as a strategy in their work. ${ }^{12,25,36}$

Ensuring adequate coordination between sectors at the national level is the 4th priority area in our study. An environment in which a common consensus and necessary coordination is achieved between all health tourism stakeholders, including both health service providers and insurance organizations and the Ministry of Health, has not been created. It is essential to create a platform where steps are taken to increase the health tourism market share, taking into account the interests of every stakeholder, where health tourism actors are together. As a matter of fact Akbolat and Deniz, they emphasized that ensuring inter-sectoral cooperation is one of the most important areas for the development of health tourism. ${ }^{38}$ Similarly Sulku, coordination should be ensured between institutions serving in the field of health tourism in our country, and the number of accredited organizations should be increased. ${ }^{39}$ With the statement that physicians and other healthcare personnel should be given the necessary training by giving importance to their foreign language skills, it has come to a conclusion that supports this opinion. In another study, they think that the health and tourism sector could not be involved in planning together enough, as one of the biggest reasons why previously developed strategies could not be fully successful. ${ }^{37}$

The development of marketing and promotional activities is of great importance in the health tourism sector as in every sector. As a matter of fact, in our study, it was determined as the fifth area among the strategy determination areas. Turkey quality and accreditation of healthcare services offered to target markets in countries within the framework of the standards and the lack of recognition as a problem is still enough of the necessary marketing activities cannot be carried emerges. In order to develop this strategic field of activity, to increase the recognition of Turkish health services and to 
guide the people of the world to talented Turkish physicians; Turkey is both highquality, cost-effective services of the package, the accredited organization, capable and well, mention of specialist physicians in the field of geo-political, socio-formed political position of cultural tourism advantage, to talk about their spa wellness facilities, potential awareness that in these types of activities area It is necessary to transfer to health tourists on international platforms. As a matter of fact, in the literature, Erdoğan and Alkanoğlu, argued that the correct and effective promotion will affect potential health tourists. ${ }^{17}$ Similarly, Akbolat and Deniz emphasized that a common guide should be prepared and branded for all health institutions in the country on medical tourism. ${ }^{38}$ Uysal Şahin and Şahin suggested that social and cultural activities and treatment should be made attractive for health tourists. ${ }^{25}$ Sulku, the selection of target markets and especially easy transportation, the various trade agreements, in countries with cultural similarities has proposed the introduction of health tourism opportunities in Turkey. ${ }^{39}$

To protect the interests of Turkey, especially with border countries, experienced shortages also affect the health tourism activities, as surely affect all tourism activities. For this reason, a policy should be developed considering the increase in the costs of health tourism activities in this sector. One of the obstacles to the incompatibility of legislation health tourism in Turkey and legal arrangements. It is essential that such legislation, which confronts health service providers, insurance companies and agencies, is updated to the benefit of health tourism. In addition, when examined past studies in order to be international, implementation of legal regulations in order to operate foreign doctors in Turkey are also recommended. ${ }^{40}$

Making necessary adjustments in pricing policies in order to ensure long-term trust in health tourists is also an important strategic area. Regulations on this subject can be secured by setting standards through the legal regulations mentioned above. By supporting our work; suggested that unnecessary treatments should be avoided for commercial purposes, pricing policies should be implemented with certain standards, and the state should control all these ethical processes through audits. ${ }^{15}$

\section{CONCLUSION AND RECOMMENDATIONS}

With this study, the strategies have been prioritized in order to reach the targeted market share in health tourism. Considering that the current studies do not go beyond SWOT analysis, this study proves that it fills an important gap in the health tourism literature.

Turkey carried out in the internationally recognized quality health care and to increase health tourists travel to the country to ensure development strategies in priority areas in order to increase Turkey's health tourism market share. The priority strategy should be the immediate implementation of the regulations that will protect both the patient (health tourist) and the physician and healthcare personnel in responsibilities resulting from malpractice practices or complications. Legal arrangements should be made as a result of the consensus reached by the Ministry of Justice, the Ministry of Tourism, insurance companies and the ministry of health. These regulations should be based on a future-oriented, comprehensive and protecting the interests of all stakeholders.

For increasing coordination with agencies and insurance companies abroad has second place in priority health tourism areas. In order to achieve this, it should be supported by conferences, fairs and events to be held to include all stakeholders at national and international level. In addition, the basis for coordination with intermediary institutions should be prepared by ensuring that all health-related outputs such as reports and 
epicrisis are organized in accordance with international standards.

Turkey's current health manpower employment point of achieving the objectives of health tourism is inadequate. For this reason, in our study, decision-makers positioned this issue in the third place in terms of priority strategy areas. Cooperation should be made with the Ministry of Health, Ministry of National Education, Council of Higher Education and Universities in order to develop this field. Strategic steps should be taken with the consensus reached by all stakeholders. In addition, various training seminars should be held regularly to increase the perception of healthcare professionals in health tourism, to provide training in the direction of current national and international legislation and to convey its importance for the country.

For each type of health tourism (Medical Tourism, Thermal Tourism, Spa \& Wellness Tourism, Geriatrics and Disabled Tourism), it is necessary to conduct separate academic studies by collecting data not only from the literature but also from the field (in terms of perspectives from patient, physician, health facilities, intermediary organizations etc.) for developing strategies. In this field where data resources are limited, primarily studies with qualitative research design can be employing. In addition, it is also important to examine and analyze the strategies of rival countries in the field of health tourism.

KAYNAKLAR

1. Bookman, M.Z. and Bookman, K.R. (2007). Medical Tourism in Developing Countries. New York: Palgrave Macmillan.

2. İçöz, O. (2009) "Sağlık Turizmi Kapsamında Medikal (Tıbbi) Turizm ve Türkiye'nin Olanakları". J Yasar Univ, 4 (14), 2257-2279.

3. Barca, M, Akdeve, E. ve Gedik Balay, İ. (2013) "Türkiye Sağlık Turizm Sektörünün Analizi ve Strateji Önerileri". İşletme Araştırmaları Dergisi, 5 (3), 64-92.

4. Büyüközkan, G, Mukul, E. and Kongar, E. (2020). "Health Tourism Strategy Selection Via SWOT Analysis and Integrated Hesitant Fuzzy Linguistic AHP-MABAC Approach". Socio-Economic Planning Sciences Published, (74), 100929

5. Kilıçarslan, M. (2019). "Swot Analysis of Health Tourism in Turkey". Elektronik Sosyal Bilimler Dergisi, (71), 1135-1145.

6. Kördeve, M.K. (2018). "Hastanelerde Stratejik Yönetim SWOT Analizi: Özel Bir Hastane Uygulaması". Sağlık Yönetimi Dergisi, 2 (1), 67-78.

7. Kostak, D. (2007). Turizm Hareketleri (Türkiye Örneği Üzerinden Sağlık Turizmi). Yüksek Lisans Tezi, Marmara Üniversitesi Sosyal Bilimler Enstitüsü, İstanbul.

8. Omay, E.G.G. and Cengiz, E. (2013). "Health Tourism in Turkey: Opportunities and Threats". Mediterr J Soc Science, 4 (10), 424-431.

9. SATURK. (2020). "Türkiye Sağlı̆̆ın Merkezi". http://www.saturk.gov.tr/images/pdf/hst/turkiyesagligin merkezi.pdf (Erişim tarihi: 6 Ocak 2021)

10. Tontuş, H.Ö. (2019). "Dünyada Sağlık Turizmi". SATURK, 14

11. Dökme, S. (2019). "Medikal Turizmde Hasta Tercihini Etkileyen Faktörler". International Social Science Studies Journal, 5 (30), 825-831.

12. Mert, G. (2013). "Sağlık Turizmi ve Uygulanbilirliği" IAAOJ Social Science, 1 (1), 103-126.

13. Özsarı, S.H. ve Karatana, Ö. (2013). "Sağlık Turizmi
Açısından Türkiye'nin Durumu" Journal Kartal Train Research Hospital, 24 (2), 136-144.

14. Demirci, Ç. (2018). Sağlık Turizminde Algilanan Değerin Müsteri Tatmini ve Sadakatine Etkisi: Sağlık Turistlerine Yönelik Bir Araştırma. Doktora Tezi, Aydın Adnan Menderes Üniversitesi Sosyal Bilimler Enstitüsü, Aydın.

15. Altsoy, S. ve Taştan Boz, İ. (2019). "Medikal Turizm Alanında Faaliyet Gösteren Hastanelerdeki Mevcu Sorunlar ve Çözüm Önerileri" Hacettepe Sağlık İdaresi Dergisi, 22 (1), 113-134

16. Aksoy, C. ve Yılmaz, S. (2019). "Sağlık Turistlerinin Hastaneleri Tercih Etme Kriterleri: Yönetici Görüşleri". Sağlık ve Sosyal Refah Araştırmaları Dergisi, 1 (2), 27 39.

17. Erdoğan, E. ve Alkanoğlu, F. (2008). "Termal Turizm ve Afyon-Gazlıgöl Örneği". e-Journal New World Science Acad Nat Appl Science, 3 (1), 83-92.

18. TÜRSAB. (2003). "SPA Turizminde Büyük Olanaklar" http://www.tursab.org.tr/dosya/1019/03eyspa_1019_174 0531.pdf (Erişim tarihi: 8 Ocak 2021).

19. Ergüven, M.H. (2010). "Wellness, Medical Wellness and Tourism". Sosyal Bilimler Dergisi, 2 (2), 86-93. doi:10.18603/std.04626

20. Akdu, U. ve Akdu, S. (2018). "Engelli Turizmi: Yasal Düzenlemeler ve Uygulamalar". Gümüshane Üniversitesi Sosyal Bilimler Enstitüsü Elektronik Dergi, 9 (23), 99-123.

21. Bektas, G. and Simsek, F. (2016). "Importance of Mobile Health Services on Old Age Tourism". Heal Care Acad Journal, 3 (4), 185.

22. İștar, E. (2016). "Health Tourism in Turkey: A Study on Newspaper". Uluslararası Sağlık Yönetimi ve Stratejileri Araştırma Dergisi, 1 (3), 26-35.

23. Aydın, D. (2014). "Türkiye Sağlık Turizmi Cep Kitabı. http://www.ipsa.org.tr/upload/kitap/visitturkeyforhealthc are-pocket-book-tr.pdf (Erişim tarihi: 12 Ocak 2021).

24. Soysal, A. (2017). "Sağlik Turizmi: Tehdit ve Fırsatlar Bağlamında Türkiye Açısından Bir Durum 
Değerlendirmesi". Uluslararası Tur ve Sosyal Araştırmalar Dergisi, (2), 169-188.

25. Uysal Şahin, Ö. ve Şahin, M. (2018). "Türkiye'de Sağllk Turizminin Potansiyeli ve Geleceği: SWOT Analizi". Journal Aware, 3 (5), 287-300

26. Özer, Ö. ve Sonğur, C. (2012). "Türkiye'nin Dünya Sağlık Turizmindeki Yeri ve Ekonomik Boyutu" Mehmet Akif Ersoy Üniversitesi Sosyal Bilim Enstitüsü Dergisi, 4 (7), 69-81.

27. Uyanık Çavuşoğlu, A. (2018). "Sağlık Turizmi Aracı Kuruluşu Hizmet Standartları Hakkında Düşünce ve Öneriler" Sağlıkta Kalite ve Akreditasyon Dergisi, 1 (2), $1-5$

28. Saaty, T.L. (1980). "Multicriteria Decision Making: The Analytic Hierarchy Process", McGraw-Hill.

29. Yang, C.C. and Chen, B.S. (2004). "Key Quality Performance Evaluation Using Fuzzy AHP". J Chinese Inst Ind Engineering, 21 (6), 543-550. doi:10.1080/10170660409509433

30. Van Laarhoven, P.J.M. and Pedrycz, W. (1983). "A Fuzzy Extension of Saaty's Priority Theory". Fuzzy Sets System, 11 (1-3), 229-241.

31. Chang, D.Y. (1996). "Applications of the Exten Analysis Method on Fuzzy AHP". Eur Journal Operation Research, 95 (3), 649-655.

32. Vahidnia, M.H. and Alesheikh, A.A. (2009) "Alimohammadi A. Hospital Site Selection Using Fuzzy AHP and Its Derivatives". Journal Environ Manage, 90 (10), 3048-3056

33. Buckley, J.J. (1985). "Fuzzy Hierarchical Analysis" Fuzzy Sets System, 17 (3), 233-247. doi:10.1016/0165 0114(85)90090-9

34. Singh, A. and Prasher, A. (2019). "Measuring Healthcare Service Quality From Patients' Perspective: Using Fuzzy AHP Application" Total Quality Management Bussines Excell, 30 (3-4), 284-300.

35. Özkan, M.E. (2019). "Sağlık Turizmi Kapsamında Türkiye'nin Medikal Turizm Potansiyeline Yönelik Bir Değerlendirme" Turk Ekonomi ve İșletme Araştırmalar Dergisi, 1 (1), 50-64.

36. Ağaoğlu, F.O, Karagöz, N. ve Zabun, S. (2019). "Sağlık Turizmi Uygulamaları ve Türkiye'ye Getirilerini İlişkin Bir Değerlendirme" 20 (2), 428-450.

37. Dinçer, M.Z, Aydoğan Cifçi, M. ve Karayılan, E. (2016) "Gelişmekte Olan Ülkelerde Medikal Turizm: Türkiye'nin Tayland, Malezya ve Hindistan'a Göre Potansiyelinin Değerlendirilmesi". İstanbul Üniversitesi Sosyal Bilimler Dergisi. (1), 34-60.

38. Akbolat, M. ve Deniz, N.G. (2017). "Türkiye'de Medika Turizmin Gelişimi ve Bazı Ülkelerle Karşılaştırılması". International Journal Global Tourism Research, 1 (2), 123-139.

39. Sulku, S.N. (2017). "Sağllk Turizminde Türkiye'nin Dünyadaki Yeri ve Potansiyeli". Uluslararası İktisadi ve İdari Bilim Dergisi, 3 (1), 99-133.

40. Aydın, O. (2012) "Türkiye'de Alternatif Bir Turizm Sağlık Turizmi". Karamanoğlu Mehmetbey Üniversitesi Sosyal ve Ekonomi Araştırmaları Dergisi, (2), 91-96. 